Egyptian J. of Nutrition Vol. XXXIV No. 2 (2019)

\title{
Preservative effect of carboxymethyl cellulose coating enriched with oregano \\ (Origanum vulgare L.) essential oil on European eel (Anguilla anguilla) fillets during cold storage
}

\author{
Mohamed E. Abdel-Aziz, Marwa R. Ali, Karima S. M. \\ Hammad, and Nashwa F. S. Morsy
}

Food Science Dep., Faculty of Agriculture, Cairo University, Egypt.

\section{Abstract}

Quality characteristics of European eel fillets coated with carboxymethyl cellulose (CMC) enriched with oregano essential oil (OEO) during cold storage were studied for 16 days. OEO was incorporated into the $\mathrm{CMC}$ coating at levels from 0 to $1.5 \%(\mathrm{v} / \mathrm{v})$.

Microbiological (total viable count and psychrophilic count), physicochemical (total volatile basic nitrogen, trimethylamine nitrogen, $\mathrm{pH}$, peroxide value, thiobarbituric acid), and sensory attributes (color, brightness, odor, texture and overall acceptability) were analyzed for the investigated fillets. The Gas Chromatography Mass Spectrum data showed that thymol was the dominant component in OEO. CMC coating with 1.5\% OEO delayed deterioration and inhibited significantly $(p<0.05)$ bacterial growth of the stored fillet samples for 16 days at $4^{\circ} \mathrm{C}$. Meanwhile control sample was acceptable only for 4 days at same temperature. Therefore, enrichment of carboxymethyl cellulose coating with OEO could extend the shelf life of fresh European eel (Anguilla anguilla) 


\section{Mohamed E. Abdel-Aziz, Marwa R. Ali, Karima S. M. Hammad, and Nashwa F. S. Morsy}

fillets and can be used as an effective alternative preservation method.

\section{Introduction}

Fresh fish is a perishable food. It should be processed quickly after fishing, otherwise it will be spoiled by enzymes and by growth of spoilage bacteria (Baklori et al., 2012). This is owing to accumulation of volatile nitrogen bases along with high final $\mathrm{pH}$ of fish that limit the storage life of the product (Duan et al., 2010). Production of European eel (Anguilla anguilla) has expanded during the recent three decades (Nielsen and Prouzet, 2008). Eels contain high level of polyunsaturated fatty acids. Fatty fish is liable to lipid oxidation and sensory deterioration during storage (Akhtar et al., 1998). The cold storage life of fresh fish is $5-10$ days according to its fat content (Eskandari et al., 2015).

One of the main challenges in food preservation is the reduction of chemical additives. Many natural plant products have received attention as natural preservatives because of their functional properties (Barros-Velazquez, 2016). Essential oils possess antioxidant and antimicrobial features. They are used in food industry to diminish the growth of food pathogens, spoilage bacteria, develop the acceptable sensory characteristics and prolong the storage life of foods. Storage-life of foods could be prolonged by a combined effect of essential oils and refrigeration (Burt, 2004).

Oregano is a herb related to Lamiaceae family. It provides the fancy flavor in common dishes (Lukas et al., 2015). Thymol of 
Egyptian J. of Nutrition Vol. XXXIV No. 2 (2019)

oregano oil possesses antioxidant and antimicrobial properties (Nazzaro et al., 2013).

Recently edible coatings gained an interest in food preservation because of the outstanding results acquired (SánchezGonzález et al., 2011). Carboxymethyl cellulose (CMC) (E466) is used in food industry as thickening and stabilizing agent. It is a nontoxic cellulose derivative and used as GRAS, with no maximum limit (Toğrul and Arslan, 2004). The aqueous film of CMC has hydrophilic affinity that enhances water vapor permeability. CMC has no antimicrobial properties. Adding essential oils to CMC coating improves its antimicrobial characteristics (Raeisi et al., 2015).

The objective of this investigation was to assess the efficacy of CMC-based coating enriched with OEO on the physicochemical, microbiological and sensory characteristics of fresh eel fillets during cold storage and determine the effect of this treatment on shelf life and the optimum OEO level required to achieve longest shelf life.

\section{Materials and Methods}

\section{Materials and Chemicals:}

Dried oregano leaves were procured from Harraz Company for Medicinal Plants, Cairo, Egypt. Identification of the leaves was conducted by the Herbarium of Orman Botanic Garden, Giza, Egypt. Ten $\mathrm{Kg}$ of fresh European eel (Anguilla anguilla) (500-800 g/eel), were purchased from the local market of fish, Cairo, Egypt. Carboxymethyl cellulose (CMC), glycerol, Tween 80 and thiobarbituric acid reagent were purchased from Sigma Aldrich, St. Louis, MO, USA. Plate count agar (PCA) was procured from Merck, 


\section{Mohamed E. Abdel-Aziz, Marwa R. Ali, Karima S. M. Hammad, and Nashwa F. S. Morsy}

Darmstadt, Germany. Other chemicals and reagents were of analytical grade.

\section{Methods:}

\section{Extraction of OEO}

Hydrodistilled OEO was collected by a Clevenger trap for $3 \mathrm{~h}$ (until no more essential oil was obtained) (Council of Europe, 2007). The extracted oil was dried by anhydrous sodium sulphate before storage at $4^{\circ} \mathrm{C}$ until use. The yield of OEO was calculated and expressed as $\mathrm{v} / \mathrm{w}$.

\section{Gas Chromatography-Mass Spectrometry}

Gas chromatography analysis was performed on a Shimadzu GCMS-QP 2010 Ultra gas chromatograph (Kyoto, Japan) fitted with flame ionization detector and RTX-5 column $(30 \mathrm{~m} \times 0.25 \mathrm{~mm}$, film thickness $0.25 \mu \mathrm{m}$ ). The carrier gas (Helium) was used at a flow rate of $1 \mathrm{~mL} / \mathrm{min}$. The injector temperature was adjusted at $210^{\circ} \mathrm{C}$ and the detector temperature was maintained at $230^{\circ} \mathrm{C}$. The split ratio was 1:50 and ionization voltage maintained at $70 \mathrm{eV}$. Injected sample volume was one $\mu \mathrm{L}$. The oven temperature program started at $40^{\circ} \mathrm{C}$ (hold time $2 \mathrm{~min}$ ) and ended at $210^{\circ} \mathrm{C}$ (hold time $5 \mathrm{~min}$ ) with a rate of $5^{\circ} \mathrm{C} / \mathrm{min}$. Identification of the volatile compounds was carried out using GC retention data, Kovats retention indices calculated by using n-hydrocarbons (C9-C22), co-injection of the authentic standards that were purchased from Fluka Chemicals (Fluka, Buchs, Switzerland) and by matching the mass spectrum of individual compounds with that of NIST and Wiley library. 
Egyptian J. of Nutrition Vol. XXXIV No. 2 (2019)

\section{Fish samples preparation}

The European eels were transported into crushed ice to the laboratory. Eels were beheaded, eviscerated, skinned, washed, and cut into rectangular shape of $6 \times 3 \times 2 \mathrm{~cm} 3$.

\section{Formulation of CMC coating}

CMC coating solution was prepared according to Raeisi et al. (2015). One-gram carboxymethyl cellulose was dispersed in $100 \mathrm{~mL}$ distilled water. Glycerol was added, as a plasticizer, into CMC coating solution at $0.5 \% \mathrm{v} / \mathrm{v}$. The dispersion was heated at $85^{\circ} \mathrm{C}$ for $5 \mathrm{~min}$ with subsequent cooling at room temperature. Emulsions of $\mathrm{CMC}$ were prepared by adding OEO at $0.5,1$ and $1.5 \%(\mathrm{v} / \mathrm{v})$ and Tween 80 as an emulsifier (10\% of the volume of the essential oil). Emulsion formation was performed at 13,500 rpm for 3 min using Highperformance disperser (IKA T25-Digital Ultra Turrax, Staufen, Germany) at room temperature.

\section{Coating formula application}

Samples were coated with CMC containing different levels of OEO. Each sample (15 pieces) from each treatment was immersed in its relevant solution at a ratio of 1:3 (fish weight/solution volume) for 5 $\min$ at $4^{\circ} \mathrm{C}$. Samples were subsequently removed and left to drain to lose the excess biopolymer solution and form the edible coating. Each treatment was packed in covered polystyrene plates $(10 \times 10$ $\mathrm{cm})$ for chemical analyses and microbiological evaluation. The samples were stored at $4^{\circ} \mathrm{C}$ for 16 days and analyses were performed at 4-day intervals. In the same time, 15 pieces were coated with only CMC with no essential oil for the same period and under the same conditions. Control sample (15 pieces) were not coated and stored under the same conditions for comparison. 


\section{Mohamed E. Abdel-Aziz, Marwa R. Ali, Karima S. M. Hammad, and Nashwa F. S. Morsy}

\section{Total viable count and total psychrophilic count}

Fish sample $(10 \mathrm{~g})$ from 3 pieces of each treatment and also from control sample was homogenized with $90 \mathrm{~mL}$ sterile saline for 2 min by a stomacher (Stomacher BW-400P, Turelab, Shanghai, China). The homogenized sample was serially diluted and then cultured in the appropriate media for microbial analyses. Total viable count (TVC) and total psychrophilic count (TPC) were enumerated on PCA after incubation at $37^{\circ} \mathrm{C}$ for $48 \mathrm{~h}$ and at $7^{\circ} \mathrm{C}$ for 10 days, respectively (Eskandari et al., 2015). The results were expressed as $\log 10$ of colony forming units per gram sample (CFU/g).

\section{Total volatile base nitrogen (TVB-N) and trimethylamine nitrogen (TMA-N)}

Twenty grams of fish sample were homogenized with $200 \mathrm{~mL}$ of aqueous trichloro-acetic acid (TCA) solution $7.5 \%(\mathrm{v} / \mathrm{v})$ for $1 \mathrm{~min}$. The homogenate was centrifuged at $1000 \mathrm{xg}$ for $5 \mathrm{~min}$, TVB-N was measured by steam distillation of the supernatant according to Malle and Poumeyrol (1989). The volatile nitrogenous components were collected in boric acid solution and determined by titration with sulphuric acid $(0.1 \mathrm{~N})$. The same procedure was conducted for TMA$\mathrm{N}$ measurement according to Malle and Tao (1987). For TMA-N measurement, $20 \mathrm{~mL}$ of formaldehyde were added to the distillation tube to fix amines other than tertiary ones. The amounts of TVB-N and TMA- $\mathrm{N}$ were expressed as $\mathrm{mg}$ nitrogen $/ 100 \mathrm{~g}$ fresh sample.

\section{pH}

Fish meat sample $(5 \mathrm{~g})$ was homogenized in $50 \mathrm{~mL}$ distilled water for $2 \mathrm{~min}$. The homogenate was filtered with two layers of cheesecloth. The filtrate was used for the determination of $\mathrm{pH}$ by a 
Egyptian J. of Nutrition Vol. XXXIV No. 2 (2019)

pH meter (Jenway, model 3305, Dunmow, Essex, UK) after calibration with two buffer solutions ( $\mathrm{pH} 4.01$ and $\mathrm{pH} 7.00)$.

\section{Peroxide value}

The method of Khan et al. (2015) was used to determine the peroxide value $(\mathrm{PV})$ of fish samples. Approximately $5 \mathrm{~g}$ sample was heated for $3 \mathrm{~min}$ at $60^{\circ} \mathrm{C}$ to enhance separating the fat before homogenization with $30 \mathrm{~mL}$ of glacial acetic acid-chloroform solution (3:2 v/v). After filtration, saturated potassium iodide solution $(0.5 \mathrm{~mL})$ was mixed with the filtrate. The mixture was kept in dark conditions for $10 \mathrm{~min}$. Distilled water and drops of starch indicator solution (1\%) were added into the mixture before titration with $0.01 \mathrm{~N}$ sodium thiosulfate. The peroxide value was expressed in meq peroxides/kg fish meat sample.

\section{Thiobarbituric acid}

Thiobarbituric acid (TBA) was determined as described by Jeon et al. (2002). Minced fish sample (5 g) was homogenized with $20 \mathrm{~mL}$ of trichloroacetic acid (TCA) solution (10\%, w/v) for $1 \mathrm{~min}$. Five $\mathrm{mL}$ of the extract solution and $5 \mathrm{~mL}$ of TBA reagent $(0.02 \mathrm{M})$ were transferred to a glass tube and mixed well. The tube was heated to $90^{\circ} \mathrm{C}$ in a water bath for $20 \mathrm{~min}$. After cooling, the absorbance of this solution was measured at $530 \mathrm{~nm}$ by Spectrophotometer (Unico UV2000, USA). TBA value (mg malondialdehyde (MDA)/kg fish tissue) was calculated using a standard curve of 1,1,3,3-tetramethoxypropane as a precursor of malondialdehyde.

\section{Sensory evaluation}

Color, brightness, odor, texture and overall acceptability of raw uncooked fish samples (coated and uncoated) were scored at the initial day of experiment and throughout cold storage according to 


\section{Mohamed E. Abdel-Aziz, Marwa R. Ali, Karima S. M. Hammad, and Nashwa F. S. Morsy}

Wierbicki (1985). Scoring was performed by ten panelists from the staff of Food Science Department, Faculty of Agriculture, Cairo University. A rating of 5 was considered as the borderline for acceptable quality.

\section{Statistical analyses}

All experiments were carried out three times and the data were analyzed using one-way analysis of variance (ANOVA) by Costat (CoHort software, Monterey, CA, USA). Duncan's multiple range test was performed at $5 \%$ significance level.

\section{Results and Discussion}

\section{Chemical composition of OEO}

The essential oil yield of oregano leaves was $1.3 \mathrm{~mL} / 100 \mathrm{~g}$. The chemical composition of the OEO is shown in Table 1 and Fig. 1. Thirty compounds were identified in the OEO, representing $93.5 \%$ of the oil. Thymol was found to be the predominant compound (33.04\%) followed by $\gamma$-terpinene, 4-terpineol, trans-sabinene hydrate, $\rho$ cymene, $\alpha$-terpineol, $\Delta$-3-carene, $\beta$-myrcene, $\alpha$-terpinolene and $\beta$ caryophyllene. These results are consistent with the studies of Hashemi and Khaneghah (2017).

\section{Changes of microbial population}

Total viable count (TVC) of the uncoated and CMC coated fresh eel fillet samples with or without OEO during cold aerobic storage are illustrated in Fig. 2a. Initial TVC (3.88 log CFU/g) of the uncoated control sample was within the acceptable bacterial load for the fresh fish as reported by Atrea et al. (2009). CMC coating without OEO reduced significantly $(p<0.05)$ the TVC value of the fresh fish 
Egyptian J. of Nutrition Vol. XXXIV No. 2 (2019)

fillets to $2.97 \log \mathrm{CFU} / \mathrm{g}$. This result is in agreement with that found by Harpaz et al. (2003).

Extending storage time was accompanied by a significant $(p<0.05)$ increase in the bacterial growth of the coated and uncoated stored samples. The maximum acceptable limit of TVC for fresh marine species is 7 log CFU/g (ICMSF, 1986). The uncoated sample and $\mathrm{CMC}$ coated samples without OEO or with OEO at $0.5 \%$ exceeded this limit after cold storage for 8, 12 and 16 days, respectively. After 4 days of storage, TVC in the samples coated with CMC+ $1.0 \%$ or $1.5 \%$ OEO was lower than that of the uncoated fillet sample by $2 \log$ CFU/g. Furthermore, TVC of these samples did not reach the maximal limit after 16 days of cold storage.

Microbiological analyses indicated that the initial TPC of the fresh uncoated sample was $3.50 \mathrm{log}$ CFU/g (Fig. 2b). The application of the CMC edible coating without OEO significantly $(p<0.05)$ reduced TPC of eel fillets by $1 \log$ CFU/g. TPC increased significantly $(p<0.05)$ over storage time at various growth rates as shown in Fig. 2. The highest rate could be noticed for the uncoated sample. TPC of the uncoated and CMC coated fillets (without OEO) exceeded the maximum permissible limit of $7.0 \log$ CFU/g (ICMSF, 1986) after 8 and 12 days of cold storage, respectively. CMC + OEO coated fillet samples did not exceed this limit at the end of 16 days. Coating fillet samples with CMC $+1.5 \%$ OEO kept TVC and TPC $<4$ CFU/g for 16 days at $4^{\circ} \mathrm{C}$, not significantly $(\mathrm{p}<0.05)$ different from those of the uncoated sample at zero time storage (Fig. 2 a\&b).

According to Nisar et al. (2019) thymol and $\beta$-caryophyllene (as ingredients with considerable levels in OEO, Table 1) disintegrate bacterial cell membrane, increase its permeability and impair the 


\section{Mohamed E. Abdel-Aziz, Marwa R. Ali, Karima S. M. Hammad, and Nashwa F. S. Morsy}

enzyme system. Coating rainbow trout fillets with quince seed mucilage films enriched with oregano and thyme essential oils decreased TVC and TPC by 2-3 log CFU/g compared to the control samples (Jouki et al., 2014).

\section{Total volatile base nitrogen (TVB-N)}

The TVB-N value of fish is used as a main index of fish freshness. Proteolytic bacteria produced TVB-N and TMA-N that are responsible for the off-flavors of fish (Bazargani-Gilani, 2017). Fish and fish products are considered unacceptable when level of TVB-N exceeded $30 \mathrm{mg} / 100 \mathrm{~g}$ (Harpaz et al., 2003). TVB-N values of the investigated samples are shown in Fig. 3a.

The TVB-N content of the fresh uncoated eel samples was $12.78 \mathrm{mg} / 100 \mathrm{~g}$ flesh. This result is in agreement with that found by Yang et al. (2015). Enrichment CMC coating with OEO lowered significantly $(p<0.05)$ TVB-N value of fresh eel fillets to $\leq 9 \mathrm{mg} / 100 \mathrm{~g}$ flesh at zero time storage. Extending storage time of all treatments was accompanied by a significant $(p<0.05)$ increase in TVB-N value. TVB-N value of the uncoated samples reached $32.13 \mathrm{mg} / 100 \mathrm{~g}$ and $68.53 \mathrm{mg} / 100 \mathrm{~g}$ after 8 and 16 days of cold storage, respectively, exceeding the maximum permissible level. Coating samples with CMC (without OEO) reduced significantly $(p<0.05)$ TVB-N than that of the uncoated fillets for four days of storage. However, coating fish fillets with CMC + OEO kept TVB-N value significantly less $(p<0.05)$ than the maximum acceptable limit until the end of storage (16 days) (Fig. 3a). Coating fillets with CMC incorporated with 1.5\% OEO maintained TVB-N value $(23.13 \mathrm{mg} / 100 \mathrm{~g})$ significantly $(p<0.05)$ lower than the other samples at the end of storage. This finding could be due to the antimicrobial activity of the OEO. 
Egyptian J. of Nutrition Vol. XXXIV No. 2 (2019)

\section{Trimethylamine nitrogen (TMA-N)}

Bacteria and enzymes reduce trimethylamine $\mathrm{N}$-oxide to TMA-N (Cakli et al., 2007). TMA-N content of the samples is shown in Fig. 3b. The proposed limit of acceptability for TMA-N was reported to be $5-10 \mathrm{mg} / 100 \mathrm{~g}$ fish muscle; otherwise it should be considered spoiled (Johnston et al., 1994). The initial TMA-N value of the uncoated sample was $3.2 \mathrm{mg} \mathrm{N} / 100 \mathrm{~g}$ indicating freshness of the fish sample as reported by Summers et al. (2017).

TMA-N concentration was $50 \%$ lower in CMC $+1 \%$ OEO and $\mathrm{CMC}+1.5 \%$ OEO coated samples, 1.8 and $1.4 \mathrm{mg} / 100 \mathrm{~g}$, respectively, at the beginning of storage. This parameter increased in all samples during storage with different rates as is shown in Fig. 3b. The highest rate could be noticed for the uncoated samples. Production of TMA-N followed the same trend as that of TVB-N. The uncoated and the coated samples with $\mathrm{CMC}$ only exceeded the tolerance level of TMA-N value after 8 and 12 days of storage, respectively. TMA-N value $(<8 \mathrm{mg} / 100 \mathrm{~g})$ of the CMC + OEO coated samples did not reach the maximum acceptable limit, even after 16 days at $4^{\circ} \mathrm{C}$. Coating with $\mathrm{CMC}+$ OEO at $1.5 \%(\mathrm{v} / \mathrm{v})$ succeeded in keeping the TMA-N content of the 16 days cold stored samples significantly $(p<0.05)$ lower than that of the 4 days stored uncoated ones. Use of OEO affected proteolytic bacteria and slowed down the decomposition in octopus muscle during chilling storage (Atrea et al., 2009).

According to microbial counts (TVC and TPC) and chemical analyses (TVB-N and TMA-N), the shelf life of uncoated cold stored samples was estimated to be less than 8 days; while it was less than 12 days in $\mathrm{CMC}$ coated samples (without OEO) and at least 16 days in $\mathrm{CMC}+1.5 \%$ OEO coated samples. 


\section{Mohamed E. Abdel-Aziz, Marwa R. Ali, Karima S. M. Hammad, and Nashwa F. S. Morsy}

pH value

The $\mathrm{pH}$ value could be used as an index for the freshness of fish (Otero-Tuárez et al., 2018). The $\mathrm{pH}$ value of eel fillet samples (coated and uncoated) during cold storage are illustrated in Fig. 4.

The $\mathrm{pH}$ value of the uncoated fresh fillets was 6.12. Storing uncoated samples for 16 days, significantly $(\mathrm{p}<0.05)$ increased $\mathrm{pH}$ value to 6.89. The $\mathrm{pH}$ value of the eel fillet samples that exceeded the maximum levels of TVB-N and TMA-N (uncoated sample cold stored for 8 days and sample coated with CMC without OEO and stored for 12 days at $4^{\circ} \mathrm{C}$ ) was $>6.4$. Chomnawang et al. (2007) found that cold storage of catfish fillets for 15 days caused an elevation in the $\mathrm{pH}$ value from 6.41 to 7.07. Sharifian et al. (2014) and Nisar et al. (2019) attributed this increase to alkaline compounds produced by the microbiological spoilage and endogenous enzymes.

Using higher levels of OEO increased the antimicrobial action of the coating formula (CMC + OEO) and inhibited the formation of basic compounds. Coating eel fillet samples with $\mathrm{CMC}$ enriched with $1.5 \%$ OEO kept $\mathrm{pH}$ value at 6.3 after 16 days of storage, not significantly $(p<0.05)$ different from that of the sample coated with CMC without OEO, at zero time. Coating rainbow trout (Oncorhynchus mykiss) slices with OEO-gelatin-alginate films slowed down the increase of $\mathrm{pH}$ during cold storage for 15 days (Kazemi and Rezaei, 2015). Pelissari et al. (2009) attributed this result to the effect of essential oil on film hydrophobic character and water absorption.

\section{Peroxide value}

Peroxide value (PV) was measured to assess lipid oxidation during cold storage of the eel fillet samples. The PV of the uncoated 
Egyptian J. of Nutrition Vol. XXXIV No. 2 (2019)

and coated fillets samples stored for 16 days at $4^{\circ} \mathrm{C}$ are illustrated in Fig. 5a.

The initial PV in the fresh samples was zero meq peroxides $/ \mathrm{kg}$ fillets. This indicates the freshness of the eel samples as reported by Okpala et al. (2014). The PV of the uncoated and all coated samples increased with the storage time. Coating eel fillets with CMC with or without OEO maintained PV less than 2 meq peroxides $/ \mathrm{kg}$ fillets until the end of storage time. Meanwhile, PV of the uncoated samples exceeded this level during the first 4 days of storage. This indicates that the CMC edible coating confers eel fillets some protection against oxidative deterioration. PV reached $6.06 \pm$ $0.10 \mathrm{meq}$ peroxides $/ \mathrm{kg}$ fillets after 16 days of cold storage of the uncoated control samples. Increasing incorporation level of OEO to $1.5 \%$ in the coating formula kept PV of the coated samples as low as $0.82 \pm 0.03 \mathrm{meq}$ peroxides $/ \mathrm{kg}$ fillet at the end of storage (16 days) at $4^{\circ} \mathrm{C}$. This could be referred to the synergistic effect of CMC and OEO as reported by Li et al. (2017).

Similar results were reported by Erkan et al. (2011) who found that homogenizing bluefish with $1 \%$ thyme essential oil kept peroxide value $\left(60.81 \mathrm{meq} \mathrm{O}_{2} / \mathrm{kg}\right.$ muscle) lower than that of the control group (76.81 meq $\mathrm{O}_{2} / \mathrm{kg}$ muscle), after 3 days of storage at $2^{\circ} \mathrm{C}$.

\section{TBA value}

The fat content of fish is oxidized during storage and forms oxidative products that caused off flavor and impairs fish quality (Raeisi et al., 2015). TBA is used as an index for lipid oxidation (Hematyar et al., 2018). The initial TBA value of the uncoated fresh fillets was $0.22 \mathrm{mg} \mathrm{MDA} / \mathrm{kg}$ eel fillets indicating freshness as reported by $\mathrm{Ke}$ et al. (1984). The data are illustrated in Fig. 5b. 


\section{Mohamed E. Abdel-Aziz, Marwa R. Ali, Karima S. M. Hammad, and Nashwa F. S. Morsy}

Extending storage time to 16 days at $4^{\circ} \mathrm{C}$ was accompanied by a gradual increase in the TBA value of the stored eel fillets with a higher rate in the case of uncoated samples. Increasing level of OEO in the CMC coating significantly $(p<0.05)$ lowered the rate of MDA formation in the stored eel fillets. Hashemi and Khaneghah (2017) attributed this antioxidant property of OEO to its high level of phenolic compounds mainly thymol. Meanwhile, the TBA value exceeded 1.0 $\mathrm{mg} \mathrm{MDA} / \mathrm{kg}$ eel fillets in the uncoated samples and samples coated with CMC only after 12 and 16 days of storage, respectively. TBA value higher than $1.5 \mathrm{mg} \mathrm{MDA} / \mathrm{kg}$ fish fillets indicates rancidity according to $\mathbf{K e}$ et al. (1984). Uncoated sample exceeded this level of TBA during cold storage for less than 16 days. At the end of storage, the lowest TBA value $(0.65 \mathrm{mg} \mathrm{MDA} / \mathrm{kg}$ eel fillets) was recorded for the sample coated with $\mathrm{CMC}+1.5 \%$ OEO. This level of TBA is acceptable for human consumption.

\section{Sensory evaluation}

Evaluation of sensory attributes is important in the quality analysis of foods. The changes in color, brightness, odor, texture and overall acceptability of the microbiologically non-rejected eel fillet samples (uncoated and coated) during storage at $4^{\circ} \mathrm{C}$ for 16 days are shown in Table 2.

The initial sensory score of the uncoated fish samples regarding their color, brightness, odor, texture and overall acceptability was $>7.5$ indicating its freshness. Coating eel fillets with CMC without OEO did not significantly $(p<0.05)$ affect the investigated sensory characteristics at the beginning of the storage period. Incorporating OEO into CMC coating improve significantly $(p<0.05)$ brightness and characteristic odor of the eel fillet samples 
Egyptian J. of Nutrition Vol. XXXIV No. 2 (2019)

(score >8.5), at zero time storage. The sensorial quality of all treatments decreased significantly $(p<0.05)$ at different rates with the extending of storage time. The CMC-OEO coatings significantly $(p<0.05)$ reduced the storage negative effect on perceived sensory attributes. On the fourth day, the uncoated samples recorded the lowest brightness and odor scores and were significantly lower than the other coated samples $(p<0.05)$. Coating eel fillet samples with CMC prepared with $1 \%$ and $1.5 \%$ OEO kept significantly $(\mathrm{p}<0.05)$ its freshness (brightness, odor and overall acceptability) for 16 days at $4^{\circ} \mathrm{C}$. The decrement of sensory attribute scores is consistent with the increment of TVB-N, TMA and TBA values.

Addition of essential oil could improve the overall quality of fish fillets and eventually prolong the shelf life of the product (Mexis et al., 2009). The application of biopolymer-based antimicrobial coatings led to significant $(p<0.05)$ increase in overall acceptability of fish fillets (Ojagh et al. 2010; Jouki et al. 2014).

\section{Conclusion}

OEO has been investigated as natural preservative in CMC coated European eel fillets during cold storage. Extending storage time negatively affected the quality indices of the uncoated and CMC (without OEO) coated samples.

$\mathrm{CMC}+\mathrm{OEO}$ coating ameliorated significantly $(\mathrm{p}<0.05)$ the increase of $\mathrm{pH}$, TVB-N, TBA, and inhibited microbial growth compared to the control. TVB-N and TMA-N correlated well with the results of microbiological analyses. 
Mohamed E. Abdel-Aziz, Marwa R. Ali, Karima S. M. Hammad, and Nashwa F. S. Morsy

The composite of CMC and OEO at $1.5 \%(\mathrm{v} / \mathrm{v})$ can be used as an edible coating to delay the oxidative degradation of eel fillets and keep its freshness for up to 16 days at $4^{\circ} \mathrm{C}$. 
Egyptian J. of Nutrition Vol. XXXIV No. 2 (2019)

Table 1. Identified volatile compounds of oregano essential oil

\begin{tabular}{|c|c|c|c|}
\hline Compound & $R_{t}(\min )^{a}$ & $\mathbf{R} \mathbf{I}^{\mathbf{b}}$ & (\%) \\
\hline$\alpha$-Thujene & 7.627 & 938 & 1.48 \\
\hline a-Pinene & 7.810 & 939 & 0.55 \\
\hline Sabinene & 9.054 & 972 & 0.58 \\
\hline$\beta$-Pinene & 9.123 & 981 & 0.25 \\
\hline$\beta$-Myrcene & 9.620 & 992 & 1.33 \\
\hline$\alpha$-Phelladrene & 9.997 & 1007 & 0.24 \\
\hline$\Delta$ 3-Carene & 10.368 & 1009 & 4.51 \\
\hline$\rho$-Cymene & 10.647 & 1025 & 7.94 \\
\hline$\beta$-phellandrene & 10.753 & 1033 & 1.51 \\
\hline Cis-Sabinene hydrate & 11.070 & 1073 & 0.09 \\
\hline Y-Terpinene & 11.700 & 1074 & 10.94 \\
\hline$\alpha$-Terpinolene & 12.624 & 1090 & 1.13 \\
\hline Trans-Sabinene hydrate & 13.161 & 1110 & 8.06 \\
\hline Cis- $\rho$-menth-2-en-1-ol & 13.855 & 1122 & 0.83 \\
\hline Trans- $\rho$-menth-2-en-1-ol & 14.441 & 1125 & 0.47 \\
\hline L-Borneol & 15.241 & 1162 & 0.12 \\
\hline 4-Terpineol & 15.482 & 1182 & 10.53 \\
\hline$\rho$-Cymen-8-ol & 15.834 & 1188 & 0.09 \\
\hline$\alpha$-Terpineol & 15.933 & 1195 & 6.29 \\
\hline Piperitol isomer & 16.051 & 1207 & 0.24 \\
\hline Cis-Piperitol & 16.469 & 1210 & 0.26 \\
\hline Endobornyl acetate & 18.598 & 1289 & 0.08 \\
\hline Carvacrol & 18.821 & 1300 & 0.12 \\
\hline Thymol & 18.982 & 1306 & 33.04 \\
\hline Trans- $\beta$-Caryophyllene & 22.089 & 1425 & 1.34 \\
\hline (+)-Aromadendrene & 22.593 & 1457 & 0.17 \\
\hline
\end{tabular}


Mohamed E. Abdel-Aziz, Marwa R. Ali, Karima S. M. Hammad, and Nashwa F. S. Morsy

Continued Table 1

\begin{tabular}{c|c|c|c}
\hline Bicyclogermacrene & 24.080 & 1502 & 0.2 \\
\hline Spathulenol & 26.175 & 1576 & 0.52 \\
\hline $\begin{array}{c}\text { Caryophyllene } \\
\text { oxide }\end{array}$ & 26.302 & 1581 & 0.51 \\
\hline Total identified (\%) & & & 93.5 \\
\hline $\begin{array}{c}\text { Total unidentified } \\
(\%)\end{array}$ & & 6.5 \\
\hline
\end{tabular}

a Retention time (RT) (as minutes)

${ }^{b} \mathrm{RI}$ retention index relative to $\mathrm{n}$-alkane under conditions listed in the Materials and methods 
Egyptian J. of Nutrition Vol. XXXIV No. 2 (2019)

Table 2. Changes in sensory attributes scores of eel samples during storage at $4^{\circ} \mathrm{C}$ for 16 days

\begin{tabular}{|c|c|c|c|c|c|}
\hline \multirow{2}{*}{ Treatments } & \multicolumn{5}{|c|}{ Time (days) } \\
\hline & Zero & 4 & 8 & 12 & 16 \\
\hline \multicolumn{6}{|c|}{ Color } \\
\hline Control & $\begin{array}{l}9.16^{a b c} \\
\pm 0.76\end{array}$ & $\begin{array}{l}7.5^{d} \\
\pm 0.5^{2}\end{array}$ & $\mathrm{R}$ & $\mathrm{R}$ & $\mathrm{R}$ \\
\hline $\mathrm{CMC}$ & $\begin{array}{l}9.16^{\mathrm{abc}} \\
\pm 1.04\end{array}$ & $\begin{array}{c}7.83^{d} \pm \\
0.28\end{array}$ & $\begin{array}{l}6.5^{\mathrm{e}} \\
\pm 0.5\end{array}$ & $\mathrm{R}$ & $\mathrm{R}$ \\
\hline $\begin{array}{c}\mathrm{CMC}+0.5 \% \\
\text { OEO }\end{array}$ & $\begin{array}{l}9.5^{\mathrm{ab}} \\
\pm 0.5\end{array}$ & $\begin{array}{l}8.5^{b c d} \\
\pm 0.5\end{array}$ & $\begin{array}{l}8.16^{\mathrm{cd}} \\
\pm 0.76\end{array}$ & $\mathrm{R}$ & $\mathrm{R}$ \\
\hline $\begin{array}{c}\mathrm{CMC}+1 \% \\
\text { OEO }\end{array}$ & $\begin{array}{l}9.66^{\mathrm{a}} \\
\pm 0.28\end{array}$ & $\begin{array}{l}9.5^{\mathrm{ab}} \\
\pm 0.5\end{array}$ & $\begin{array}{l}8.5^{\text {bcd }} \\
\pm 0.5\end{array}$ & $\begin{array}{l}8.16^{\text {cd }} \\
\pm 0.28\end{array}$ & $\begin{array}{l}7.5^{d} \\
\pm 0.5\end{array}$ \\
\hline $\begin{array}{c}\mathrm{CMC}+1.5 \% \\
\text { OEO }\end{array}$ & $\begin{array}{l}9.83^{a} \\
\pm 0.28\end{array}$ & $\begin{array}{c}9.66^{\mathrm{a}} \pm \\
0.57\end{array}$ & $\begin{array}{l}9.16^{a b c} \\
\pm 0.76\end{array}$ & $\begin{array}{l}8.16^{\text {cd }} \\
\pm 0.28\end{array}$ & $\begin{array}{l}7.83^{d} \\
\pm 0.76\end{array}$ \\
\hline \multicolumn{6}{|c|}{ Brightness } \\
\hline Control & $\begin{array}{l}7.5^{\text {ef }} \\
\pm 0.5\end{array}$ & $\begin{array}{l}7.0^{f} \\
\pm 0.5\end{array}$ & $\mathrm{R}$ & $\mathrm{R}$ & $\mathrm{R}$ \\
\hline $\mathrm{CMC}$ & $\begin{array}{c}8.5^{\text {cde }} \\
\pm 0.5\end{array}$ & $\begin{array}{l}8.5^{\text {cde }} \\
\pm 0.5\end{array}$ & $\begin{array}{l}7.0^{f} \\
\pm 0.5\end{array}$ & $\mathrm{R}$ & $\mathrm{R}$ \\
\hline $\begin{array}{c}\mathrm{CMC}+0.5 \% \\
\text { OEO }\end{array}$ & $\begin{array}{l}9.33^{a b c} \\
\pm 0.76\end{array}$ & $\begin{array}{l}8.66^{\text {bcd }} \\
\pm 0.28\end{array}$ & $\begin{array}{l}7.83^{\text {def }} \\
\pm 0.76\end{array}$ & $\mathrm{R}$ & $\mathrm{R}$ \\
\hline $\begin{array}{c}\mathrm{CMC}+1 \% \\
\text { OEO }\end{array}$ & $\begin{array}{l}9.5^{a b c} \\
\pm 0.5\end{array}$ & $\begin{array}{l}9.5^{a b c} \\
\pm 0.5\end{array}$ & $\begin{array}{l}8.5^{\text {cde }} \\
\pm 0.5\end{array}$ & $\begin{array}{l}8.5^{\text {cde }} \\
\pm 0.5\end{array}$ & $\begin{array}{l}7.5^{\text {ef }} \\
\pm 0.5\end{array}$ \\
\hline $\begin{array}{c}\mathrm{CMC}+1.5 \% \\
\text { OEO }\end{array}$ & $\begin{array}{r}10^{a} \\
\pm 0.0\end{array}$ & $\begin{array}{c}9.66^{\mathrm{ab}} \pm \\
0.57\end{array}$ & $\begin{array}{c}8.83^{\mathrm{bcd}} \\
\pm 0.76\end{array}$ & $\begin{array}{l}8.66^{\text {bcd }} \\
\pm 0.57\end{array}$ & $\begin{array}{l}7.83^{\text {def }} \\
\pm 0.76\end{array}$ \\
\hline \multicolumn{6}{|c|}{ Odor } \\
\hline Control & $\begin{array}{l}7.66^{\text {bcd }} \\
\pm 0.28\end{array}$ & $\begin{array}{l}6.16^{f} \\
\pm 0.57\end{array}$ & $\mathrm{R}$ & $\mathrm{R}$ & $\mathrm{R}$ \\
\hline $\mathrm{CMC}$ & $\begin{array}{l}7.5^{\mathrm{cde}} \\
\pm 0.5\end{array}$ & $\begin{array}{l}7.5^{\text {cde }} \\
\pm 0.5\end{array}$ & $\begin{array}{l}6.66^{\text {ef }} \\
\pm 0.28\end{array}$ & $\mathrm{R}$ & $\mathrm{R}$ \\
\hline $\begin{array}{c}\text { CMC }+0.5 \% \\
\text { OEO }\end{array}$ & $\begin{array}{l}8.5^{b} \\
\pm 0.5^{2}\end{array}$ & $\begin{array}{l}8.5^{b} \\
\pm 0.5\end{array}$ & $\begin{array}{l}8.0^{b c} \\
\pm 0.0\end{array}$ & $\mathrm{R}$ & $\mathrm{R}$ \\
\hline
\end{tabular}


Mohamed E. Abdel-Aziz, Marwa R. Ali, Karima S. M. Hammad, and Nashwa F. S. Morsy

Continued Table 2

\begin{tabular}{|c|c|c|c|c|c|}
\hline $\mathrm{CMC}+1 \%$ OEO & $\begin{array}{l}9.5^{a} \\
\pm 0.5\end{array}$ & $\begin{array}{l}9.5^{a} \\
\pm 0.5^{2}\end{array}$ & $\begin{array}{l}8.16^{b c} \\
\pm 0.28\end{array}$ & $\begin{array}{l}8.16^{b c} \\
\pm 0.28\end{array}$ & $\begin{array}{l}7.0^{\text {def }} \\
\pm 0.5\end{array}$ \\
\hline $\mathrm{CMC}+1.5 \%$ OEO & $\begin{array}{r}9.66^{\mathrm{a}} \\
\pm 0.57\end{array}$ & $\begin{array}{l}9.66^{a} \\
\pm 0.57\end{array}$ & $\begin{array}{l}8.5^{b} \\
\pm 0.5\end{array}$ & $\begin{array}{l}8.33^{b c} \\
\pm 0.57\end{array}$ & $\begin{array}{l}7.83^{b c d} \\
\pm 0.76\end{array}$ \\
\hline \multicolumn{6}{|l|}{ Texture } \\
\hline Control & $\begin{array}{l}9.83^{a} \\
\pm 0.28\end{array}$ & $\begin{array}{l}7.0^{\text {ef }} \\
\pm 0.5\end{array}$ & $\mathrm{R}$ & $\mathrm{R}$ & $\mathrm{R}$ \\
\hline CMC & $\begin{array}{l}9.83^{a} \\
\pm 0.28\end{array}$ & $\begin{array}{l}7.5^{d e} \\
\pm 0.5\end{array}$ & $\begin{array}{c}6.5^{f} \\
\pm 0.86\end{array}$ & $\mathrm{R}$ & $\mathrm{R}$ \\
\hline $\mathrm{CMC}+0.5 \% \mathrm{OEO}$ & $\begin{array}{l}9.83^{a} \\
\pm 0.28\end{array}$ & $\begin{array}{l}8.0^{\text {cd }} \\
\pm 0.5\end{array}$ & $\begin{array}{l}8.0^{c d} \\
\pm 0.5\end{array}$ & $\mathrm{R}$ & $\mathrm{R}$ \\
\hline $\mathrm{CMC}+1 \% \mathrm{OEO}$ & $\begin{array}{l}9.83^{a} \\
\pm 0.28\end{array}$ & $\begin{array}{l}8.83^{b c} \\
\pm 0.28\end{array}$ & $\begin{array}{l}8.5^{b c} \\
\pm 0.5\end{array}$ & $\begin{array}{l}8.0^{c d} \\
\pm 0.5\end{array}$ & $\begin{array}{l}7.0^{\text {ef }} \\
\pm 0.5\end{array}$ \\
\hline $\mathrm{CMC}+1.5 \%$ OEO & $\begin{array}{l}10.0^{\mathrm{a}} \\
\pm 0.0\end{array}$ & $\begin{array}{l}9.66^{a} \\
\pm 0.57\end{array}$ & $\begin{array}{l}9.33^{\mathrm{ab}} \\
\pm 0.57\end{array}$ & $\begin{array}{l}8.66^{b c} \\
\pm 0.57\end{array}$ & $\begin{array}{l}8.16^{\text {cd }} \\
\pm 0.28\end{array}$ \\
\hline \multicolumn{6}{|l|}{ Overall acceptability } \\
\hline Control & $\begin{array}{l}8.0^{c d} \\
\pm 0.5\end{array}$ & $\begin{array}{l}6.5^{f} \\
\pm 0.5\end{array}$ & $\mathrm{R}$ & $\mathrm{R}$ & $\mathrm{R}$ \\
\hline CMC & $\begin{array}{l}8.0^{c d} \\
\pm 0.5\end{array}$ & $\begin{array}{l}7.5^{\mathrm{de}} \\
\pm 0.5\end{array}$ & $\begin{array}{c}6.5^{\dagger} \\
\pm 0.5\end{array}$ & $\mathrm{R}$ & $\mathrm{R}$ \\
\hline $\mathrm{CMC}+0.5 \%$ OEO & $\begin{array}{c}8.5^{a b c} \\
\pm 0.5\end{array}$ & $\begin{array}{l}8.16^{\text {bcd }} \\
\pm 0.28\end{array}$ & $\begin{array}{l}8.16^{\text {bcd }} \\
\pm 0.28\end{array}$ & $\mathrm{R}$ & $\mathrm{R}$ \\
\hline $\mathrm{CMC}+1 \% \mathrm{OEO}$ & $\begin{array}{l}9.16^{\mathrm{a}} \\
\pm 0.28\end{array}$ & $\begin{array}{l}9.0^{a b} \\
\pm 0.5\end{array}$ & $\begin{array}{l}8.16^{\text {bcd }} \\
\pm 0.28\end{array}$ & $\begin{array}{l}7.66^{\text {cde }} \\
\pm 0.57\end{array}$ & $\begin{array}{l}7.0^{\text {ef }} \\
\pm 0.5\end{array}$ \\
\hline $\mathrm{CMC}+1.5 \% \mathrm{OEO}$ & $\begin{array}{l}9.33^{\mathrm{a}} \\
\pm 0.28\end{array}$ & $\begin{array}{l}9.33^{\mathrm{a}} \\
\pm 0.57\end{array}$ & $\begin{array}{l}9.33^{a} \\
\pm 0.57\end{array}$ & $\begin{array}{l}8.5^{a b c} \\
\pm 0.5\end{array}$ & $\begin{array}{l}7.66^{\text {cde }} \\
\pm 0.76\end{array}$ \\
\hline
\end{tabular}

Values are given as mean \pm standard deviation $(n=3)$. Means with the same letter in the same sensory attribute are not significantly different $(P<0.05)$. R rejected microbiologically 
Egyptian J. of Nutrition Vol. XXXIV No. 2 (2019)

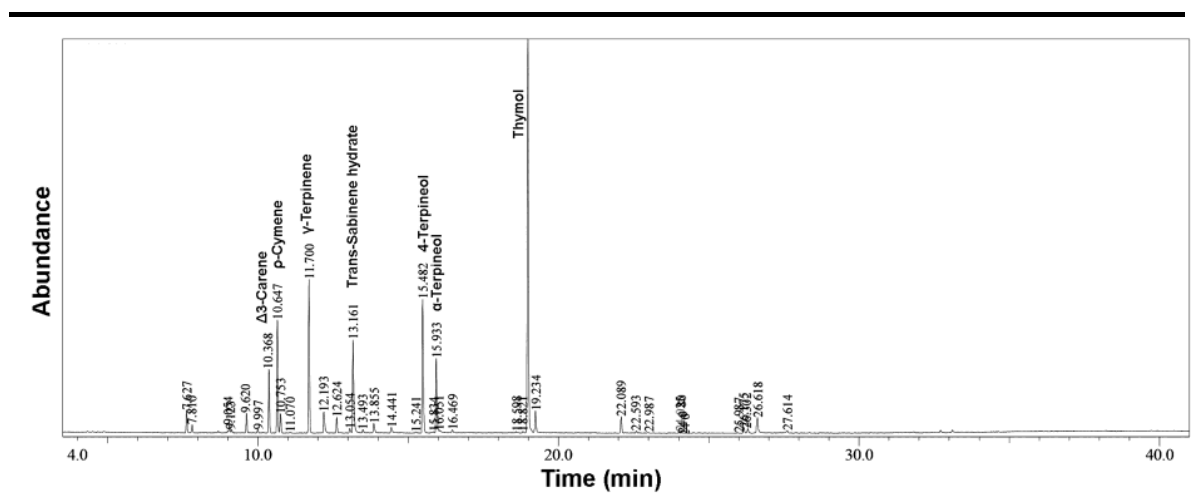

Fig. 1. GC-MS chromatogram of oregano essential oil 
Mohamed E. Abdel-Aziz, Marwa R. Ali, Karima S. M. Hammad, and Nashwa F. S. Morsy

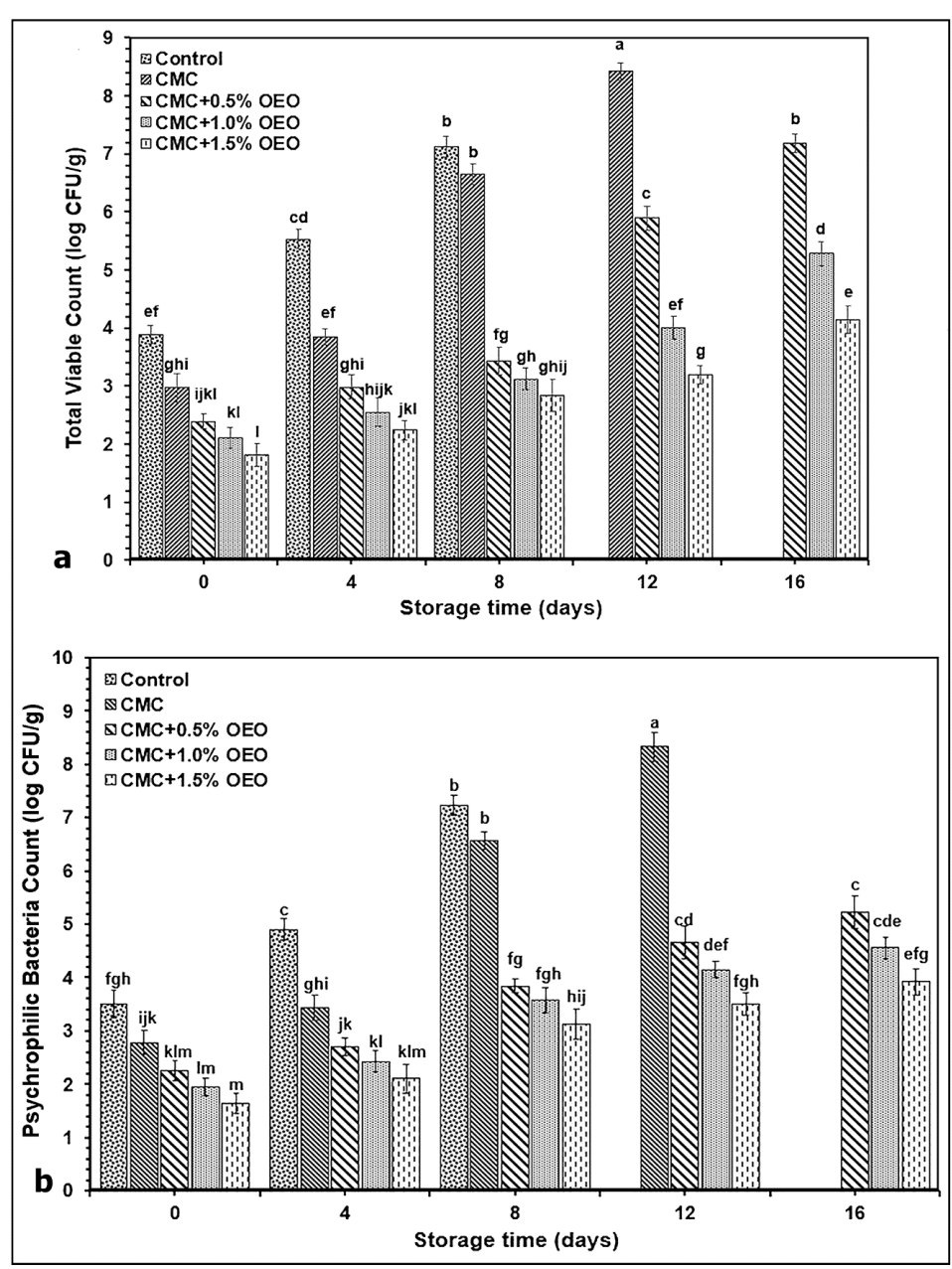

Fig 2. (a) Total viable count (TVC) and (b) Psychrophilic bacterial count (TPC) of coated eel fillets with CMC film incorporated with OEO during storage for 16 days at $4^{\circ} \mathrm{C}$. Same superscript letter above the bars denote non-significant difference $(p>0.05)$ 
Egyptian J. of Nutrition Vol. XXXIV No. 2 (2019)

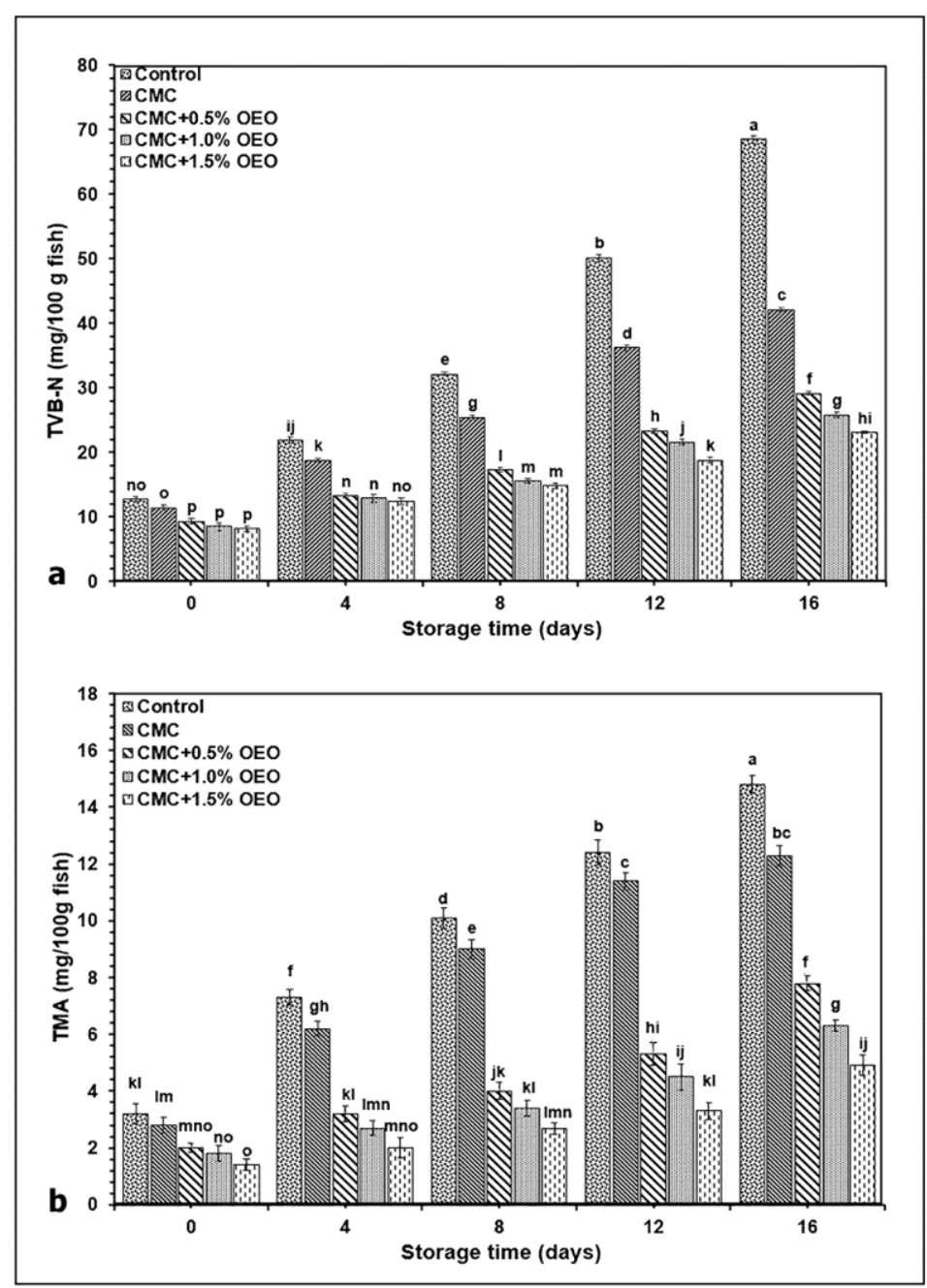

Fig 3. (a) TVB-N, (b) TMA-N values of eel fillets coated with CMC film incorporated with OEO during storage for 16 days at $4^{\circ} \mathrm{C}$. Same superscript letter above the bars denote non-significant difference $(p>0.05)$ 
Mohamed E. Abdel-Aziz, Marwa R. Ali, Karima S. M. Hammad, and Nashwa F. S. Morsy

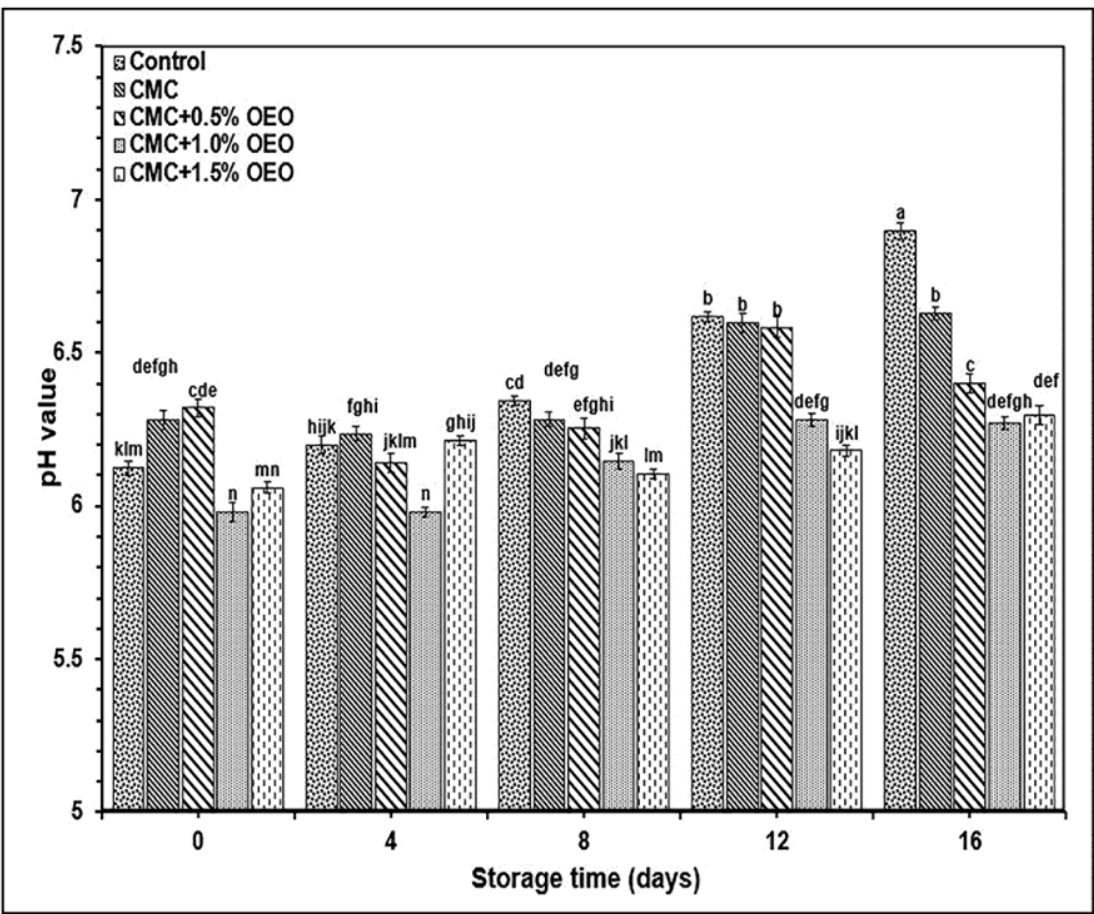

Fig 4. $\mathrm{pH}$ values of eel fillets coated with $\mathrm{CMC}$ film incorporated with OEO during storage for 16 days at $4^{\circ} \mathrm{C}$. Same superscript letter above the bars denote non-significant difference $(p>0.05)$ 
Egyptian J. of Nutrition Vol. XXXIV No. 2 (2019)
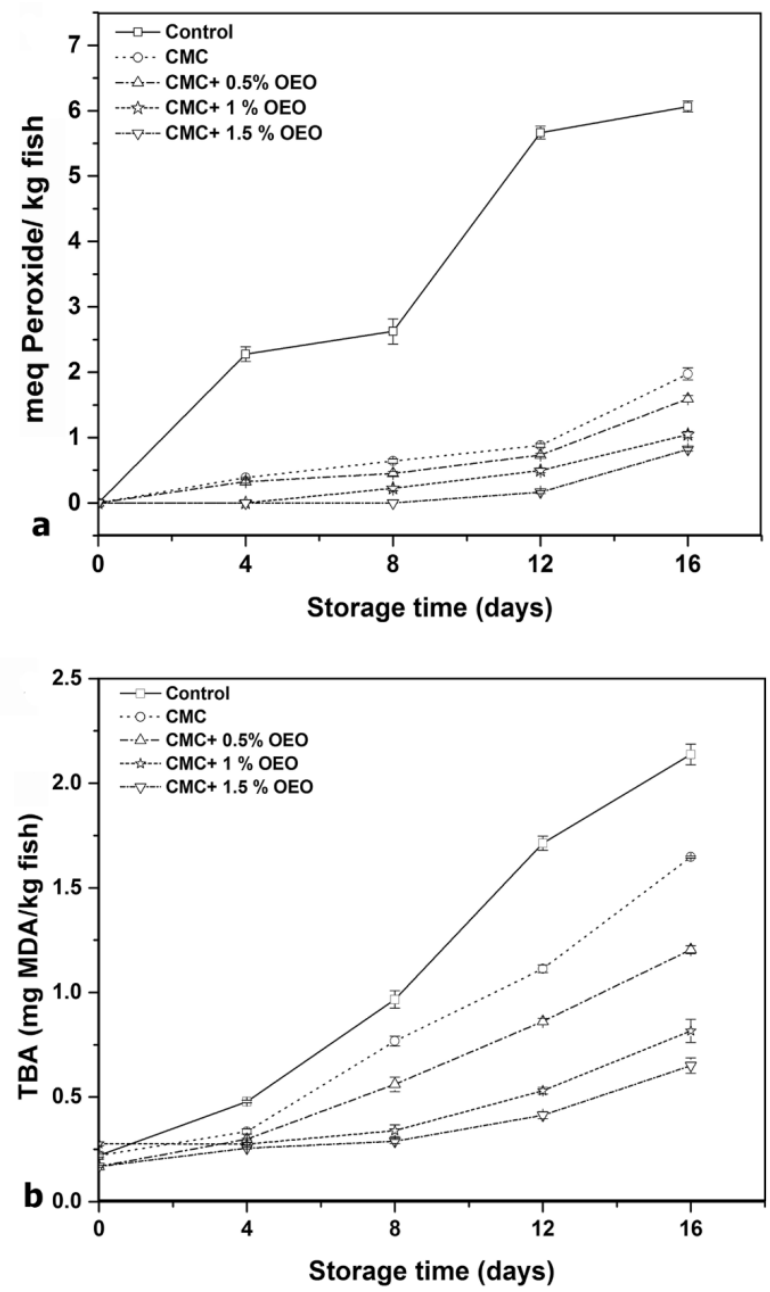

Fig 5. (a) Peroxide and (b) TBA values of eel fillets coated with $C M C$ film incorporated with OEO during storage for 16 days at $4^{\circ} \mathrm{C}$. Same superscript letter above the bars denote non-significant difference $(p>0.05)$ 
Mohamed E. Abdel-Aziz, Marwa R. Ali, Karima S. M. Hammad, and Nashwa F. S. Morsy

References

Akhtar, P., Gray, J. I., Booren A. M. and Garling, D. L. (1998).

Effect of dietary components and surface application of oleoresin rosemary on lipid stability of rainbow trout (Oncorhynchus mykiss) muscle during refrigerated and frozen storage. J Food Lipids., 5:43-58.

Atrea, I., Papavergou, A., Amvrosiadis I. and Savvaidis, I. N. (2009).

Combined effect of vacuum-packaging and oregano essential oil on the shelf-life of Mediterranean octopus (Octopus vulgaris) from the Aegean Sea stored at $4^{\circ} \mathrm{C}$. Food Microbiol., 26:166-172.

Baklori, C., Tsironi T. and Taoukis, P. (2012).

"Predictive modelling of the shelf life of smoked fish." CE Food 2012 - Proceedings of 6th central European congress on food, pp. 923-927.

Barros-Velazquez, J. (2016).

"Antimicrobial food packaging." $1^{\text {st }}$ edition, San Diego, Academic Press. 
Egyptian J. of Nutrition Vol. XXXIV No. 2 (2019)

Bazargani-Gilani, B. (2017).

Activating sodium alginate-based edible coating using a dietary supplement for increasing the shelf life of rainbow trout fillet during refrigerated storage $\left(4 \pm 1^{\circ} \mathrm{C}\right)$. J Food Saf., 38:1-9.

Burt, S. 2004.

Essential oils: their antibacterial properties and potential applications in foods-a review. Int J Food Microbiol., 94:223253.

Cakli, S., Kilinc, B., Cadun, A., Dincer T. and Tolasa, S. (2007).

Effects of gutting and ungutting on microbiological, chemical, and sensory properties of aquacultured sea bream (Sparus aurata) and sea bass (Dicentrarchus labrax) stored in ice. Crit Rev Food Sci Nutr., 46:519-527.

Chomnawang, C., Nantachai, K., Yongsawatdigul, J., Thawornchinsombut, S. and Tungkawachara, S. (2007).

Chemical and biochemical changes of hybrid catfish fillet stored at $4^{\circ} \mathrm{C}$ and its gel properties. Food Chem., 103:420427.

Council of Europe (COE) (2007).

"European Directorate for the Quality of Medicines." European Pharmacopoeia. $6^{\text {th }}$ edition, Strasbourg. 
Mohamed E. Abdel-Aziz, Marwa R. Ali, Karima S. M. Hammad, and Nashwa F. S. Morsy

Duan, J., Cherian, G. and Zhao. Y. (2010).

Quality enhancement in fresh and frozen lingcod (Ophiodon elongates) fillets by employment of fish oil incorporated chitosan coatings. Food Chem., 119:524-532.

Erkan, N., Tosun, S. Y., Ulusoy, S. and Uretener, G. (2011). The use of thyme and laurel essential oil treatments to extend the shelf life of bluefish (Pomatomus saltatrix) during storage in ice. Journal of Consumer Protection and Food Safety 6:3948.

Eskandari, S., Hosseini, H., Gholamzadeh, M., Khaneghah, A. M. and Hosseini, E. (2015).

The effects of black cumin, black caraway extracts and their combination on shelf life extension of silver carp (hypophthalmichthys molitrix) during refrigerated storage. $\mathrm{J}$ Food Saf., 35:154-160.

Harpaz, S., Glatman, L., Drabkin, V. and Gelman, A. (2003).

Effects of herbal essential oils used to extend the shelf life of freshwater-reared Asian sea bass fish (Lates calcarifer). J Food Prot., 66:410-417.

Hashemi, S. M. B. and Khaneghah, A. M. (2017).

Characterization of novel basil-seed gum active edible films and coatings containing oregano essential oil. Prog Org Coat 110:35-41. 
Egyptian J. of Nutrition Vol. XXXIV No. 2 (2019)

Hematyar, N., Masilko, J., Mraz, J. and Sampels, S. (2018).

Nutritional quality, oxidation, and sensory parameters in fillets of common carp (Cyprinus carpio L.) influenced by frozen storage $\left(-20^{\circ} \mathrm{C}\right) . \mathrm{J}$ Food Process Preserv., 42:1-13.

International Commission on Microbiological Specifications for Foods (ICMSF). (1986).

"Microorganisms in Foods. Sampling for Microbiological Analysis: Principles and specific applications." Vol. 2. University of Toronto Press, Toronto, Canada.

Jeon, Y. J., Kamil, J. Y. V. A. and Shahidi, F. (2002).

Chitosan as an edible invisible film for quality preservation of herring and Atlantic cod. J. Agric. Food Chem., 50:5167-5178.

Johnston, W. A., Nicholson, F. J., Roger, A. and Stroud, G. D. (1994).

"Quality Assessment." In: Freezing and refrigerated storage in fisheries. Chapter 3. FAO Fisheries Technical Paper No. 340, FAO, Rome, $143 \mathrm{p}$.

Jouki, M., Yazdi, F. T., Mortazavi, S. A., Koocheki, A. and Khazaei, N. (2014).

Effect of quince seed mucilage edible films incorporated with oregano or thyme essential oil on shelf life extension of refrigerated rainbow trout fillets. Int J Food Microbiol., 174:8897. 
Mohamed E. Abdel-Aziz, Marwa R. Ali, Karima S. M. Hammad, and Nashwa F. S. Morsy

Kazemi, S. M. and Rezaei, M. (2015).

Antimicrobial effectiveness of gelatin-alginate film containing oregano essential oil for fish preservation. J Food Saf., 35:482-490.

Ke, P. J., Cervantes, E. and Robles-Martinez, C. (1984).

Determination of thiobarbituric acid reactive substances (TBARS) in fish fillet by an improved distillation spectrophotometric method. J Sci Food Agric., 35:1248-1254.

Khan, M. I., Adrees, M. N., Arshad, M. S., Anjum, F. M., Jo, C. and Sameen, A. (2015).

Oxidative stability and quality characteristics of whey protein coated rohu (Labeo rohita) fillets. Lipids Health Dis., 14:58-66.

Li, T., Jiang, Y., Li, J. and Hu, W. (2017).

An investigation on quality of Japanese sea bass (lateolabrax japonicas) using chitosan assisted with Origanum vulgare oil and allicin. J Food Process Preserv., 41:e12918.

Lukas, B., Schmiderer, C. and Novak, J. (2015).

Essential oil diversity of European Origanum vulgare L. (Lamiaceae). Phytochemistry 119:32-40. 
Egyptian J. of Nutrition Vol. XXXIV No. 2 (2019)

Malle, P. and Poumeyrol, M. (1989).

A new criterion for the quality control of fish, trimethylamine/total volatile basic nitrogen (\%). J. Food Prot., 52:419-423.

Malle, P. and Tao, S. H. (1987).

Rapid quantitative determination of trimethylamine using steam distillation. J Food Prot., 50:756-760.

Mexis, S., Chouliara, E. and Kontominas, M. (2009).

Combined effect of an oxygen absorber and oregano essential oil on shelf-life extension of rainbow trout fillets stored at $4^{\circ} \mathrm{C}$. Food Microbiol., 26:598-605.

Nazzaro, F., Fratianni, F., De Martino, L., Coppola, R. and De Feo, V. (2013).

Effect of essential oils on pathogenic bacteria. Pharmaceuticals 6:1451-1474.

Nielsen, T. and Prouzet, P. (2008).

"Capture-based aquaculture of the wild European European eel (Anguilla anguilla)." In: Lovatelli, A. and Holthus, P. F. (Eds.), Capture-based aquaculture: Global overview, Rome, FAO Fisheries Technical Paper. No. 508. pp. 141-168. 
Mohamed E. Abdel-Aziz, Marwa R. Ali, Karima S. M. Hammad, and Nashwa F. S. Morsy

Nisar, T., Yang, X., Alim, A., Iqbal, M., Wang, Z-C., and Guo, Y. (2019).

Physicochemical responses and microbiological changes of bream (Megalobrama ambycephala) to pectin based coatings enriched with clove essential oil during refrigeration. Int J Biol Macromol., 124:1156-1166.

Ojagh, S. M., Rezaei, M., Razavi, S. H. and Hosseini, S. M. H. (2010).

Development and evaluation of a novel biodegradable film made from chitosan and cinnamon essential oil with low affinity toward water. Food Chem., 122:161-166.

Okpala, C. O. R., Choo, W. S. and Dykes, G. A. (2014).

Quality and shelf life assessment of Pacific white shrimp (Litopenaeus vannamei) freshly harvested and stored on ice. LWT-Food Sci Technol., 55:110-116.

Otero-Tuárez, V., Carrión-Granda, X., Fernández-Pan, I., Fernández, T. and Maté, J. I. (2018).

Combined effect of antimicrobial edible coatings with reduction of initial microbial load on the shelf-life of fresh hake (Merluccius merluccius) medallions. Int J Food Sci Technol., $54: 835-843$. 
Egyptian J. of Nutrition Vol. XXXIV No. 2 (2019)

Pelissari, F. M., Grossmann, M. V. E., Yamashita, F. and Pineda, E. A. G. (2009).

Antimicrobial, mechanical, and barrier properties of cassava starch-chitosan films incorporated with oregano essential oil. J Agric Food Chem., 57:7499-7504.

Raeisi, M., Tajik, H., Aliakbarlu, J., Mirhosseini, S. H. and Hosseini, S. M. H. (2015).

Effect of carboxymethyl cellulose-based coatings incorporated with Zataria multiflora Boiss. essential oil and grape seed extract on the shelf life of rainbow trout fillets. LWT-Food Sci Technol., 64:898-904.

Sánchez-González, L., Vargas, M., González-Martínez, C., Chiralt, A. and Cháfer, M. (2011).

Use of essential oils in bioactive edible coatings: a review. Food Eng Rev., 3:1-16.

Sharifian, S., Alizadeh, E., Mortazavi, M. S. and Moghadam, M. S. (2014).

Effects of refrigerated storage on the microstructure and quality of Grouper (Epinephelus coioides) fillets. J Food Sci Technol., 51:929-935. 
Mohamed E. Abdel-Aziz, Marwa R. Ali, Karima S. M. Hammad, and Nashwa F. S. Morsy

Summers, G., Wibisono, R. D., Hedderley, D. I. and Fletcher, G. C. (2017).

Trimethylamine oxide content and spoilage potential of New Zealand commercial fish species. New Zeal J Mar Fresh., $51: 393-405$.

Toğrul, J. and Arslan, N. (2004).

Carboxymethyl cellulose from sugar beet pulp cellulose as a hydrophilic polymer in coating of mandarin. J Food Eng., 62:271-279.

Wierbicki, E. (1985).

"Food Irradiation Processing." Vienna, Austria: IAEA Publications. $79 \mathrm{p}$.

Yang, F., Hu, S., Lu, Y., Yang, H., Zhao, Y. and Li, L. (2015). Effects of coatings of polyethyleneimine and thyme essential oil combined with chitosan on sliced fresh Channa argus during refrigerated storage. J Food Process Eng., 38:225233. 
Egyptian J. of Nutrition Vol. XXXIV No. 2 (2019)

التأثير الحافظ للتظية بكربوكسى ميتيل سليلوز مدعم بالزيت العطرى

اوريجانو

لثشر ائح سمك الثعابين

الأوروبي

أثناء التخزين بالتبريد

\section{محمد عماد الدين عبد العزيز، مروة رشاد على،

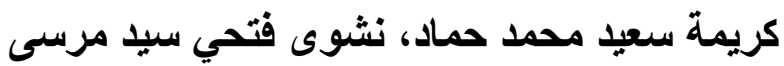

قسم علوم الاغذية ـ كلية الزر اعة - جامعة القاهرة

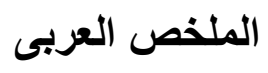

تم دراسة خصائص الجودة لثرائح سمك الثعابين الأوروبي (Anguilla anguilla)

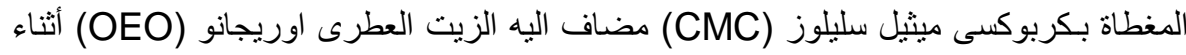

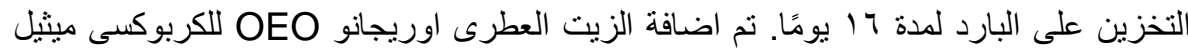
سليلوز CMC بمستويات من صفر إلى 0, 1, (حجم / حجم).

تم اجراء تحاليل ميكروبيولوجية (العد الكلى للخلايا البكتيرية الحية، العد الكلى للبكتريا

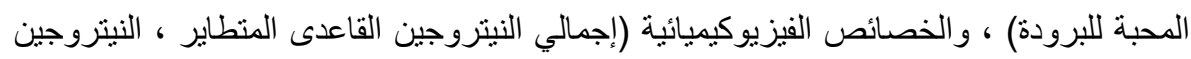

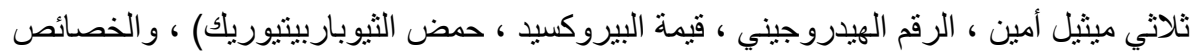

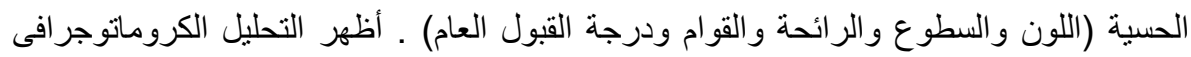

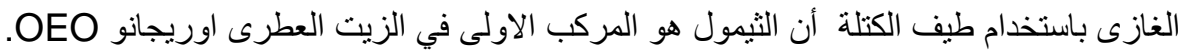

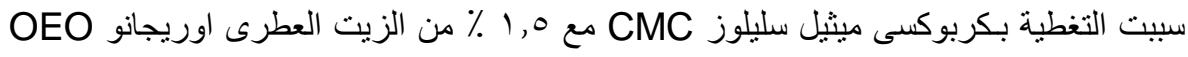

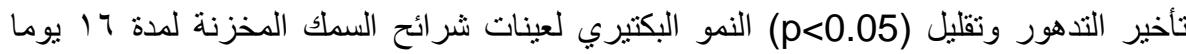

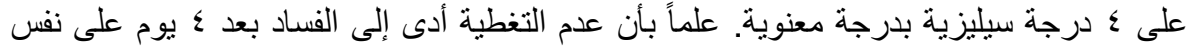

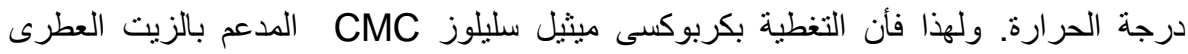

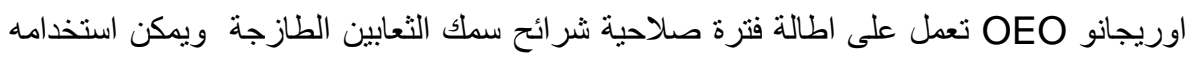
كطريقة من طرق الحفظ الفعالة و البديلة لددة تصل إلى الى 17 يوم في ثلاجة على ؛ درجة سليليزية. 
Mohamed E. Abdel-Aziz, Marwa R. Ali, Karima S. M. Hammad, and Nashwa F. S. Morsy 